\author{
(online) $=$ ISSN $2285-3642$ \\ ISSN-L = 2285 - 3642 \\ Journal of Economic Development, Environment and People \\ Volume 3, Issue 4, 2014 \\ URL: http://jedep.spiruharet.ro \\ e-mail: office jedep@spiruharet.ro
}

\title{
Sustainable Environment and in the Context of Environment Economy Necessary and an Analyze
}

\author{
Gunes UNAL ${ }^{1}$, M. Sakir Başaran ${ }^{2}$, Selcuk KENDIRLI ${ }^{3}$ \\ ${ }^{1}$ Turkish Court of Accounts, Ankara, 06520, Turkey \\ ${ }^{2}$ Turkish Court of Accounts, Ankara, 06520, Turkey \\ ${ }^{3}$ Hitit University FEAS Banking and Finance, Akkent 3. Cadde No:3, Corum,19100, Turkey
}

\begin{abstract}
In global world, the environment has become a scarce resource. Since economics is about how to deal with scarce resources, environment and economics are interrelated with each other. On the other hand it is also clear that economics which creates both positive and negative externalities, affects the environment. For this reason, it is not possible to except environmental problems from the economics. Today some socio-economic activities like increasing consumption based on shopping malls, urban regeneration, fast population growth and etc. have being created environmental cost.
\end{abstract}

One way of using economics is to ensure that the costs and the benefits of environmental measures are well balanced. Although it is difficult to estimate costs and benefits, there is an increasing demand that this is should be done before the economical activity.

Economic and environmental objectives are often perceived as being contradictory. It is believed that a choice must be made between one and the other and that cannot be achieved concurrently. To change this perception, some measures should be taken on both national and international level. At this point, an efficient environmental auditing is being important day by day to ensure environmental economics.

In this study we will research what was done in the world in terms of environmental economics. In this context, we will examine what will have to do in Turkey in terms of legislation?

Key Words: Environment, Sustainable Environment, Environmental Economy

JEL Codes: Q00, Q50

\footnotetext{
${ }^{1}$ Turkish Court of Account, Inönü Bulvari (Eskisehir Yolu) No:45 Balgat/Çankaya/Ankara, 06520, Turkey, Tel: +90 (312) 29530 00, Fax: + 90 (312) 29540 94, Email: selcukkendirli@hitit.edu.tr

${ }^{2}$ Turkish Court of Account, Inönü Bulvari (Eskisehir Yolu) No:45 Balgat/Çankaya/Ankara, 06520, Turkey, Tel: +90 (312) 29530 00, Fax: + 90 (312) 29540 94, Email: selcukkendirli@hitit.edu.tr

${ }^{3}$ Hitit University FEAS Banking and Finance, Akkent 3. Cadde No:3, Corum,19100, Turkey

Tel: +905423239238, Fax: +903642257710, Email: selcukkendirli@hititiedu.tr
} 


\author{
(online) $=$ ISSN $2285-3642$ \\ ISSN-L = 2285 - 3642 \\ Journal of Economic Development, Environment and People \\ Volume 3, Issue 4, 2014 \\ URL: http://jedep.spiruharet.ro \\ e-mail: office jedep@spiruharet.ro
}

\title{
1. The Relationship between Economics and the Environment
}

\subsection{Concepts of Economy and the Environment}

Economy is a complete activity which satisfies human needs. While economy maintains these activities, it has to ensure the usage of resources in the direction of unlimited needs. Because the man's needs are unlimited but goods and services which satisfy these needs are always scarce and limited. Since the disparity between "needs" and "goods services" which satisfies these needs exist in developed or underdeveloped, capitalist or socialist, all communities, this is called "Law of Scarcity". [http:// bbs. bartin. edu. tr/ dosyalar/ Ders Materyal/44866u2ve3k\%C4\%B1tl\%C4\%B1kkanunualternmalyt.pdf, 25.06.2014] And while economy fulfills its main function which is to meet needs of human, it creates positive and negative externalities.

While, environment is a component which creates inputs of economy with its resources, it is also integrity of systems affected by negative externalities of the economy. Therefore, the close relationship between economy and the environment makes economy manage the environment which has a limited source.

In a general meaning, environment is a place, which human communities and the other lives continue their lives and make use of natural resources. A different identification for environment is as flows; environment is the sum of physical, chemical and social factors which has an immediate or direct or indirect effect on human activities and live assets in a particular time. [Kaya, 2006]

No matter in which context environment is used, the concept of environment usually emphasizes, "to be at the center and to be out of the center". Therefore, environment is defined the opposite of a center and in this sense; it is an "external" phenomenon. [Özdek, 1993]

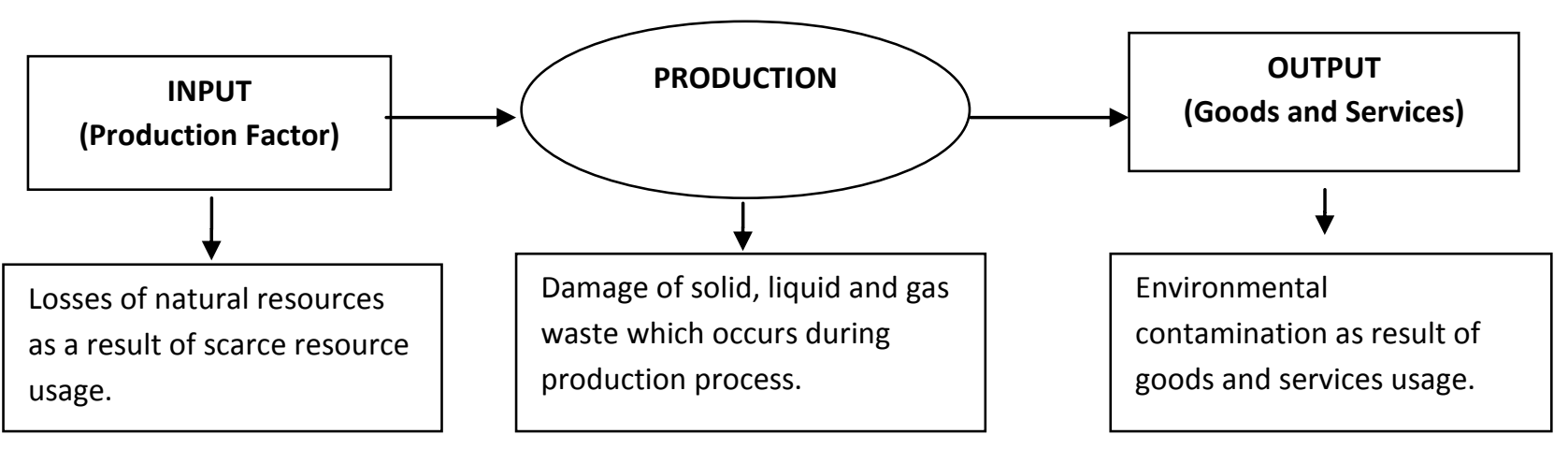

Fig. 1: Business - Natural Environment Relationship

Source: KAYA Uğur, (2006), İşletme-Doğal Çevre Illişkilerinin Mali Tablolar Aracılığıyla Raporlanması ve Denetimi, SPK Yayınları,p.31

While the environment is seen an external phenomenon affected by the output of the production process - goods and services -, it is also a large concept includes production factors -inputs- . In this sense, 


\author{
(online) $=$ ISSN $2285-3642$ \\ ISSN-L = 2285-3642 \\ Journal of Economic Development, Environment and People \\ Volume 3, Issue 4, 2014 \\ URL: $\underline{\text { http://jedep.spiruharet.ro }}$ \\ e-mail: office jedep@spiruharet.ro
}

environment provides inputs to economy, as well as it is affected by the externalities created by economy. Today, both businesses and countries are in the discussion of unlimited natural resources which the environment provides as an input to economy. Therefore, environmental costs are currently being processed to minimize by both volunteer applications and legal regulations.

In this respect Environmental Economics can be defined as; "A specific sub-field of Economics, in which environmental issues is taken from an economic perspective, a contribution to economy with the protection of environment and natural resources, and also the way of the minimizing environmental pollution. [http://www.nedirnedemek. com/\%C3\%A7evre-ekonomisi-nedir-\%C3\%A7evre-ekonomisi-nedemek, 26.06.2014]

Today environmental economics has become more and more important comparing to the past in order to ensure the continuous activity of economy which is done through with scarce resources, and also as a result of the broad concept of environment including both affects economy with its factors of production and affected by the externalities of economy. So; as Al Gore, the vice-president of USA and also specialist on environmental problems says that "Holding on to the old argument that the environment and the economy are in conflict is really outdated". [Press Release; "Sierra Club Endorses Gore", 2000]

\title{
1.2. The History of Environmental Economics
}

There are differences between the conventional economics and neo-classic economics approaches on environmental issues. While quantity was considered in classic economics, quality was also taken into account in neo-classic economics. According to classical economists such as J.B. Say and Adam Smith, natural resources were characterized as free goods and excluded from the economic analysis. A. Pigou, a neo-classic economist, put environmental concept into the economic analysis, and so laid the foundations of environmental economics.

A. Marshall is the first name contributing economic analysis of environmental problems. According to Marshall, market economy's inefficiency lies in back of the basic reason of environmental pollution. He spoke first time about the externalities in his work published in 1890. And Keynes who is one of the important economists in the last term, has created a discussion platform up to this day about the externalities of environmental pollution will be resolved/or not resolved by market mechanism. [Yıldırım \& Marin, 2004]

\section{Environmental Issues}

Environmental cost of economy creates environmental problems. Too tight and bilateral relations are available between economic development and environmental issues. Economic development is a cause, and environmental issues are foregone conclusion of it. Environmental problem usually includes all cons which occur on environmental values (water, air, soil, etc.) as a result of human activities. In that context the first issue coming to mind is "pollution" problem. [Kaya, 2006] 


\author{
(online) $=$ ISSN $2285-3642$ \\ ISSN-L = $2285-3642$ \\ Journal of Economic Development, Environment and People \\ Volume 3, Issue 4, 2014 \\ URL: $\underline{\text { http://jedep.spiruharet.ro }}$ \\ e-mail: office jedep@spiruharet.ro
}

Environmental pollution is the deterioration which damages natural stability of environment and makes up catastrophic exposures on living beings as a result of dirty air, dirty water, and dirty wastes which are caused by the production process to satisfy human needs. [Özdek, 1993]

It has occurred major changes on natural balance of earth climate and evolution due to the usage of fossil fuels which is emitted into the atmosphere from gases that cause the greenhouse effect used from Industrial Revolution. So; "Global Warming" is a significant other environmental problem which is the natural result of economic activities, finding a place as an international concept and is defined as "in the increase of average temperatures of the world's lands, seas and air seen throughout the year." [http://tr.wikipedia.org/wiki/K\%C3\%BCresel_\%C4\%B1s\%C4\%B1nma, 26.06.2014]

\title{
2.1. Main Causes of Environmental Pollution
}

Environmental pollution is the specific term of the environmental issue. Although it is put forwarded so many factors causes of the environmental pollution, three basic titles are; population growth, urbanization and industrialization [Kaya, 2006]. In fact these three basic titles have a relationship with each other on a cause-effect base. For example, increasing population pressure creates illegal immigration and in that context creates urban growth, so with it industrialization occurs to ensure economic dynamic.

Today, rapid population growth and as a result of it urbanization and related to it urban transformation and constructions have been increasing environmental costs of economy. In particular, with the reasons of like urban transformation projects and change in consumer oriented approaches such as shopping malls, it has been in progress no return- construction buildings, so does the damage to the environment is increasing in the same or a higher rate. It is also questionable that the contribution of these constructions to the economy besides from their damage to the environment. Perhaps, one of the best examples of it is; the big stadiums which have been built for the World Football Cup 2014 in Brazil. It has been criticized because of their management on a "use and throw" base. In accordance with, the construction industry in 2014 Athens Olympic Games has become an economic downturn for Greece as well as its damage to the environment.

\subsection{Approaches to Solve Environmental Problems}

\subsubsection{National Approaches}

Developed countries are accepted which have already completed industrialization process, while developing countries have selected the industrialization path before performing transition process of farming to industry. So, this rapid and uncontrolled industrialization creates serious adverse effects on the environment. [http://journal.dogus.edu.tr/ojs/ index.php/duj/article/view/175/191, 03.07.2014] Both in developed and in developing countries there is a pressure on environment created by economy, so in recent years environmental concept given priority among the topics. 


\author{
(online) $=$ ISSN $2285-3642$ \\ ISSN-L = $2285-3642$ \\ Journal of Economic Development, Environment and People \\ Volume 3, Issue 4, 2014 \\ URL: $\underline{\text { http://jedep.spiruharet.ro }}$ \\ e-mail: office jedep@spiruharet.ro
}

The most effective approach for solving environmental problems is to get rid of those elements that cause the problem. This solution is far from being "rational"; it is just "radical". Rational solution approaches can be put in ordered as; Sustainable Development, Cost-Benefit Analysis, Environmental Impact Assessment and other approaches. [Kaya, 2006]

\title{
- Sustainable Development -Sustainability
}

Economy is required into the basis of "Sustainable Development" to get rid of the negative effect creates on the environment. It is possible to make the description of "Sustainable Development" as follows; The plan of today's life and the future's development with establishing a balance between man and nature by without the risk of damaging natural resources and ensuring the usage of resources consciously. [http://www.bilgiustam.com/surdurulebilir-kalkinma-nedir, 25.06.2014] In addition a broad consensus exists that it means that economic activities should be consistent with: sustainable use of renewable natural resources, protection of ecosystem features and functions, preservation of biological diversity, a level of harmful emissions remaining below critical (assimilative) thresholds, and avoidance of irreversible damage to the environment and nature. [Mulder \& Jeroen \& Bergh, 2001]

Sustainability works both for minimizing the loss of environmental damage created by economy and also recycling this loss into economy again. In this sense, production technologies will be required compatible with nature, as well as having efficient and productive technologies. Therefore implementation of renewable energy sources has become essential in the natural part of production process to contribute to "environmental sustainability".

One of the best examples has been Sweden, in the sense that environment has been returned to the economy on the subject of sustainable development. Sweden head of all countries about recycling, solar energy and many more sustainable practices and a country maintains large part of its heating-up needs from garbage, has started to import waste from its the nearest neighbor Norway. Even, it is about 80.000 tons of waste imported from Norway. [http://www.ntvmsnbc.com/id/25436041; İsveç'in çöpü bitti, 25.06.2014]

In this sense, sustainability is the concept which has to be implemented essentially day by day to create a coil in the economy and to hold a dynamic standing of environment. We also provide a sustainable development, while our environment can be converted back. Environmental economy more in case of ecological sense, the aim becomes; "...,to protect, to continue and to use again and again." [Areuea Journal, 1978. Available at http://web.a.ebscohost.com/ehost/pdfviewer] 


\author{
(online) $=$ ISSN $2285-3642$ \\ ISSN-L = $2285-3642$ \\ Journal of Economic Development, Environment and People \\ Volume 3, Issue 4, 2014 \\ URL: $\underline{\text { http://jedep.spiruharet.ro }}$ \\ e-mail: office jedep@spiruharet.ro
}

\title{
- Cost \& Benefit Analysis
}

Cost - Benefit Analysis is quite a well-developed method for determining the net returns to a Project over a period of time; the only necessary correction is the inclusion of environmental costs or benefits. [Dutta, 2003]

To use Cost and Benefit Analysis as a solution on the environmental issues, environmental impacts on investments should be used as a data. In other words, it should be calculated as a quota by summing up cash returning and positive impact of the investment, and as a denominator again by summing up the cash outflows of the investment and negative impact on environment by investment made and then agree that the ratio of quota to denominator will be the "cost - benefit ratio". By using this ratio, both environmentally sound investments can be selected and also problems can be prevented at the planning stage.

However, although cash outflows (costs) regarding negations on the environment can be calculated to a degree, cash inflows regarding the positive effects on environment cannot be calculated. This makes the approach's applicability quite difficult. [Kaya, 2006]

Despite its well-known limitations, benefit-cost analysis can be a key method for consistently assimilating the disparate information that is pertinent to sound decision making. If properly done, it can be of great help to public officials as they seek to identify environmental targets and goals.

\section{- Environmental Impact Assessment}

Environment has to be placed on a legal ground to lighten the pressure on it created by industrialization. So in order to increase both economic developments of countries and environmental quality, "Environmental Impact Assessment" is an international concept found a place.

Environmental Impact Assessment, is an approach which analyses the effects of an activity in which sense it affects the environment (directly or indirectly, positively or negatively) in the decision making phase of it. It is also an approach to identify the alternative solutions to minimize that may be made by the adverse effect of the activity. Known as Environmental Impact Assessment (EIA) approach, the report must be drawn up before the investment decisions for the prevention and seeing of possible effects on environment created by the investment. This is called; "Environmental Impact Assessment Report" or simply called EIA report. [Kaya, 2006]

While Environmental Impact Assessment approach resembles the other environmental problem solution approach - Cost Benefit Analysis- in the way of positive and negative aspects of the investments on the environment, it is a more comprehensive approach. In addition, in this approach as it is not compulsory to use numbers for all the data, it is also easier to use. [Kaya, 2006] 


\author{
(online) $=$ ISSN $2285-3642$ \\ ISSN-L = $2285-3642$ \\ Journal of Economic Development, Environment and People \\ Volume 3, Issue 4, 2014 \\ URL: $\underline{\text { http://jedep.spiruharet.ro }}$ \\ e-mail: office jedep@spiruharet.ro
}

\title{
- Environmental Law
}

With all of above, Environmental Law's popularity has also continued to increase in accordance with today's conditions. To protect and improve the environment, to establish rules for both preventing environmental pollution and compensating for damages, to create resources for all of these regulations and to recommend sanction are all in the field of Environmental Law. [http://www.sayistay.gov.tr/vayin/vayinicerik/145.k1Cevsemtr.pdf, 06.07.2014]

\section{- Government Policy}

Environmental pollution created by the negative externalities of an economy can be resolved in a wellfunctioning price system. If price system is installed, both less polluting technologies are encouraged and a fair distribution for the environmental pollution costs will be made.

However even a well-functioning market system may be remained as inactive for diminishing the environmental pollution. For some reason, task begins to fall to the public economy as a solution for the prevention of environmental pollution which has a right to use fiscal policy tools and policies such as taxes and/or subsidies.

\subsubsection{International Regulations}

It is inevitable in terms of the work for countries resolving environmental problems. However, the work made globally, enforces countries a tighter co-operation and in the natural sense it would be more incentive. This co-operation around the world for the environmental protection has been doing by dual or multi-sided agreements on international environmental law.

In this respect the first global environmental policies created as UNEP (United Nations Environment Program) followed by a meeting in Stockholm in 1972 by the United Nations.

In addition Kyoto Protocol in 1997, a single-frame to ensure the fight both for global warming and climate change which are one of the main problems of today is also an important international regulation on environment.

Some major policy options were set in the process of which starts with UNEP and continues along Kyoto Protocol, including reduction of fossil fuel usage, development of renewable energy sources to ensure the energy needed and also efficient use of energy. The use of new technologies and particularly technology has been another policy options to help the countries which have not yet been completed development processes. [Yıldırım \&Marin, 2004] 


\author{
(online) $=$ ISSN $2285-3642$ \\ ISSN-L = $2285-3642$ \\ Journal of Economic Development, Environment and People \\ Volume 3, Issue 4, 2014 \\ URL: $\underline{\text { http://jedep.spiruharet.ro }}$ \\ e-mail: office jedep@spiruharet.ro
}

\title{
3. Contribution of Environmental Auditing on Environmental Economics
}

Environmental controls which will make a contribution on environmental economics must also be taken into consideration. The basic distinctive feature of environmental controls of course focuses on environmental issues and aims at improving the environment which is both today's and the future's basic public supply for all of humanity and ensuring sustainable use of it. [http://www.sayistay.gov.tr/yayin/yayinicerik/145.k1Cevsemtr.pdf, 06.07.2014]

From this point of view, countries' external audit component that is Court of Accounts' have to perform important tasks to assess the use of public source.

\subsection{Types of Environmental Auditing}

As it is known that the management of resolving environmental issues has been regularized which both in national and international laws and agreements, Court of Accounts can be given as part of the service of "Legality Audit" for the protection and development of the environment. In this sense, Court of Accounts' can follow the conformity in accordance with laws and international environment contracts as a public source.

If the use of environmental resources (air, water, soil, etc.) and its usage effects are recorded correctly, a "Financial Audit" may also be possible for environmental affairs. [http://www.sayistay.gov.tr/yayin/yayinicerik/145.k1Cevsemtr.pdf, 06.07.2014]

With the path of "Performance Audit", it is carried out by monitoring in environmental programs, the environmental impact of other programs, environmental management systems, and/or environmental agreements. [http://www.sayistay.gov.tr/yayin/ yayinicerik/145.k1Cevsemtr.pdf, 06.07.2014] So a new concept has occurred called " $4 \mathrm{E}$ " which includes economy, efficiency, effectiveness and environment also the base of "Performance Audit" .

\section{Conclusion}

Economy and the environment have been seen as two dynamic concepts which replaces on the same plane within difficulty. It is believed that a choice must be made between one and the other and that cannot be achieved concurrently. But the importance of the both national and international works to change this approach is increasing.

In this regard, it should be created protection - based environmental economies both nationally and internationally. In addition, it should be generated economic policies that doesn't see the environmental problems as a natural result of the economic activities and takes into account the environment and its value. 


\author{
(online) $=$ ISSN $2285-3642$ \\ ISSN-L = 2285 - 3642 \\ Journal of Economic Development, Environment and People \\ Volume 3, Issue 4, 2014 \\ URL: http://jedep.spiruharet.ro \\ e-mail: office jedep@spiruharet.ro
}

A positive bilateral relationship between economy and the environment can be ensured by sustainable development. Therefore it should be aimed an environmentally sustainable economies - Eco-Economies. The cost of protecting the environment without polluting it is cheaper than bringing a contaminated environment back to its old one. As a result clean and nature-friendly technologies are preferred, and yet again, if there still any pollutants they have to be recycled. [http://www.sayistay.gov.tr/yayin/yayinicerik/145.k1Cevsemtr. pdf,06.07.2014]

Another point to make popular environmentally sustainable economies (eco-economy) is that; it is necessary to work with economists and ecologists. Only economists and ecologists who work together might build on its future continues today. [Uğur \&, Marin, 2004]

Besides "Sustainable Development", Cost - Benefit Analysis approach should be used to help for creating effective policies to protect environment from the negative externalities of economic activities.

However while population growth affects urbanization and industrialization and so both economic development and environmental problems in terms of countries, also causes an increase in global environmental issues. It is therefore; perhaps population control policies have to grow up globally as an example of today's China. According to Gore; the world is expected to have more than 9 billion people by 2075, with much of that growth coming from developing countries in Africa. So; Gore argues an alarming point that "Fertility Management" is needed to address a whole slew of global development issues, including mitigating global warming. [http://nation.foxnews.com/2014/01/28/al-gore-suggests-fertilitymanagement-fight-global-warming , 03.07.2014]

In addition an environmental damage occurs with urbanization and constructions caused by the natural result of population growth and internal migration. So, to reduce the effects of environmental damage, it has to be built up a healthy and a balanced urbanization policy and this policy should be performed by providing sustainability. All next-generation, neighbors, living creatures and the environment must be taken into account. [Akyel, 2013]

One of the important reasons which create environmental issues is that "Efficiency" isn't given the importance in production and consumption activities as well as in resource allocation and technology usage. So technology helps to developing countries to be focused on a solution proposition.

In resolving environmental problems, environmental monitoring should also be seen as an effective instrument, so it requires co-operating of more than one country's Court of Accounts. [http://www.sayistay.gov.tr/yayin/yayinicerik/145.k1Cevsemtr.pdf ,06.07.2014]

In addition, the importance of implementation of informative and conservative environmental policies is undeniable. While it is thought that "Standards of Protection of the Environment" make a positive contribution to economy by creating new business courses, it also may be incentive for the countries to 


\author{
(online) $=$ ISSN $2285-3642$ \\ ISSN-L = 2285 - 3642 \\ Journal of Economic Development, Environment and People \\ Volume 3, Issue 4, 2014 \\ URL: http://jedep.spiruharet.ro \\ e-mail: office jedep@spiruharet.ro
}

ensure the interaction between economy and the environment. And again, Al-Gore says; "We can improve our economy and create millions of good new jobs if we go about building the new technologies that can help us clean up the environment." [Press Release; "Sierra Club Endorses Gore", 2000]

\title{
References
}

[1] Areuea Journal (1978), Areuea Journal, Journal of the American Real Estate \&Urban Economics. Available at http://web.a.ebscohost.com/ehost/pdfviewer

[2] AKYEL R. (2013); The President of Turkish Court of Accounts ,p.41.

[3] Dutta M. (2003) New Economic Dimensions in Economic Thought: The Case of Environmental Economics, Journal of the Alumni Association of the Economics Department Calcutta University, pp.95-109.

[4] http://bbs.bartin.edu.tr/dosyalar/DersMateryal/44866u2ve3k\%C4\%B1t|\%C4\%B1kka nunualternmalyt.pdf

[5] http://journal.dogus.edu.tr/ojs/index.php/duj/article/view/175/191

[6] http://nation.foxnews.com/2014/01/28/al-gore-suggests-fertility-management-fight-global-warming

[7] http://tr.wikipedia.org/wiki/K\%C3\%BCresel_\%C4\%B1s\%C4\%B1nma

[8] http://www.bilgiustam.com/surdurulebilir-kalkinma-nedir

[9] http://www.nedirnedemek.com/\%C3\%A7evre-ekonomisi-nedir-\%C3\%A7evre-ekonomisi-ne-demek

[10] http://www.ntvmsnbc.com/id/25436041; İsveç'in çöpü bitti

[11] http://www.sayistay.gov.tr/yayin/yayinicerik/145.k1Cevsemtr.pdf

[12] Mulder P.; Jeroen C.J.M.; Bergh V. D. (2001), Evolutionary Economic Theories of Sustainable Development, Blackwell Publishers.

[13] ÖZDEK, Y. E. (1993) İnsan Hakkı Olarak Çevre Hakkı, TODAIE Yayınları.

[14] Press Release. (2000) "Sierra Club Endorses Gore".

[15] Stavins; R. N. (2000) A Draft- A Two-Way Street between Environmental Economics and Public Policy, Edward Elgar Publishing Inc.

[16] Yıldırım U.; Marin M. C. (2004) Çevre Sorunlarına Çağdaş Yaklaşımlar, Beta Yayınları.

[17] Yrd. Doç. Dr. KAYA, U. (2006) İşletme-Doğal Çevre illişkilerinin Mali Tablolar Aracılığıyla Raporlanması ve Denetimi, SPK Yayınları. 